\title{
The Validation of Smart Entrepreneur Model (SEM) for Student Using Exploratory Factor Analysis (EFA)
}

\author{
Asmar Yulastri ${ }^{\mathrm{a}, *}$, Muharika Dewi ${ }^{\mathrm{b}}$, Hendra Hidayat ${ }^{\mathrm{c}}$, Zadrian Ardi ${ }^{\mathrm{d}}$, Yuliana ${ }^{\mathrm{a}}$ \\ ${ }^{a}$ Faculty of Tourism and Hospitality, Universitas Negeri Padang, Padang, 25132, Indonesia \\ ${ }^{b}$ Universitas Putra Indonesia, Padang, 25221, Indonesia \\ ${ }^{c}$ Faculty of Engineering, Universitas Negeri Padang, Padang, 25132, Indonesia \\ ${ }^{d}$ Faculty of Education, Universitas Negeri Padang, Padang, 25132, Indonesia \\ Corresponding author: *asmaryulastri.unp@gmail.com
}

\begin{abstract}
The entrepreneurial student program reflects the Indonesian government's growing emphasis on the necessity of developing entrepreneurship skills and mindsets among university students. However, a method for implementing this program has not been thoroughly defined. This research aims to examine the validity of the Smart Entrepreneur Model (SEM) construct using Exploratory Factor Analysis (EFA). A research and development approach were used. It was divided into three stages. This study aims to describe the outcome of the second step, which is the statistical analysis test with EFA. It summarizes the findings of an examination of the SEM construct. The model's construction consists of nine phases: 1) Training Program Preparation, 2) Psychometric Test (pretest), 3) Determination of Mentor Selection Participants, 4) Training, 5) Project Work, 6) Project Monitoring, 7) Seminar and Report, 8) Psychometric Tests (Posttest), and 9) Project Evaluation. EFA was performed to analyze construct validity with the aid of IBM SPSS Amos 20. This construct validity test was performed on 72 randomly selected students who participated in a SEM course. They were asked to complete a questionnaire. The EFA results are valid. In fact, of the nine phases studied, there is only one with an Eigenvalue greater than one. In terms of phase development in this training model experiment, it is possible to infer that the 9 phases examined have created a unified model. As a result, the SEM entrepreneurship training approach is valid.
\end{abstract}

Keywords - Construct validity; exploratory factor analysis; model smart entrepreneur; engineering educations.

\section{INTRODUCTION}

Research and development dealing with entrepreneurship learning have received great attention from researchers and academics in many countries. These efforts are intended to find a solution to the low achievement of entrepreneurial education goals. The research findings indicate that the students and the graduates who started entrepreneurship tended to be low in number even though entrepreneurship education had been massively provided $[1,2]$. Government, universities, and other concerning parties keep improving entrepreneurship learning because of the importance of entrepreneurship education in human resources issues. The focus of developing entrepreneurial skills lies in economic development through new business opportunities, new technology, innovation, efficiency, and productivity [3].

As a fundamental goal of entrepreneurship, the growth of entrepreneurs influences the economic growth of a country
[4]. Opportunities to develop community welfare in a country will be realized if the resources driving entrepreneurship can be well optimized [5]. One of the ways to develop these resources is enhancing entrepreneurial education in universities, which can be integrated into various student development programs that the government directly supervises.

Responding to these challenges, since 2009, the Indonesian government has launched an Entrepreneurial Student Program called "Program Kewirausahaan Mahasiswa" (henceforth PMW) that higher education institutions developed through the Directorate General of Technical Education, Ministry of Education and Culture, especially in engineering education. The PMW is implemented in all state universities. This program also aims to encourage entrepreneurial institutions or units of the universities to support entrepreneurship programs' development. That way, it is expected that there will be a decrease in education 
graduates' unemployment rate. One of the ways to realize this program is training.

The training aims to equip, improve, and develop work competencies to improve abilities, productivity, and welfare [6]. Mentoring and coaching inexperienced trainees by an experienced trainer in providing information, support, and encouragement are also called apprenticeships. Many training models have been carried out in various countries to support the success of an entrepreneurship program in entrepreneurship education using the concept of partnership between campuses and the entrepreneurial communities. The results suggest a relationship formed between campuses, students, organizations, and companies in the communities, promoting integrated development entrepreneurship [6,7]. The partnership between schools or campuses and communities has elements and functions as a social capital concept to identify social norms and customs incorporated in the social environment with trust from each environment.

Each model has advantages and disadvantages in several aspects of its application. Although the primary goals remain the same (increasing the number of entrepreneurial students active and productive), each model's needs are undoubtedly different. The importance of basic behaviors as a characteristic that needs to be studied before doing an action in training students in entrepreneurship cannot be ignored.

Evaluating to find out students' index entrepreneurship is a fundamental step to facilitate the formation of education and training patterns that will be carried out through appropriate mentoring methods. Then, training is related to the specific nature of what is known as 'competence,' which consists of characteristics, skills, knowledge, and attitudes [8]. Therefore, strategies to consider all composites of competence are essential to ensure the success of implementing entrepreneurship programs.

A developed training model for college graduates in the first year of graduation in higher education focused on various skills such as business skills, personality dimensions, entrepreneurial characteristics, and project-based training methods to overcome unemployment [9]. This model is applied to graduates to increase their focus in training because they will have greater responsibility for entrepreneurship than the students who are still in their education. The developed entrepreneurial training model to overcome the diversity of students' backgrounds is a module validated by experts. This model has allowed students to learn independently each of the necessary abilities for Aboriginal students [10].

The developers of an entrepreneurship training model in China that depart from experience in developing Entrepreneurship education programs in the country stated that the Project Competition Model in entrepreneurship education had established ten pilot universities as pilot projects competing for entrepreneurship [11, 12]. The competition emphasized technological innovation, commercialization technology, high technology industry, and improving concentration on talent training that could increase competitiveness capacity in entrepreneurship.

They developed a three-stage Student Entrepreneurship Encouragement Model (SEEM Model) to encourage students to become entrepreneurs in three different universities [13]. SEEM is an ideal way to introduce students to become interested in receiving offers of entrepreneurial cooperation from other universities. The main objective of SEEM model is to generate active entrepreneurs, primarily by increasing entrepreneurial awareness as a career choice for students. Yet, this model has a long-term program and involves many colleges allowing it to be executed with a high degree of seriousness at the universities involved.

In the preliminary research of this current study, an Entrepreneurship index assessment has been carried out to 497 students of Universitas Negeri Padang (the State University of Padang, Indonesia). The results indicate that the Student Summary Index of Entrepreneurship Score were 74\% for entrepreneurial attitudes, $77 \%$ for internal locus control, $66 \%$ for business motivation, $65 \%$ for self-confidence in entrepreneurship, $77 \%$ for achievement, $66 \%$ for simple risktaking, $73 \%$ for entrepreneurial moral values, $73 \%$ for entrepreneurship, and 79\% for entrepreneurial behavior.

Responding to the need for economic growth challenges and entrepreneurial models, especially in Indonesia, the researchers developed a Smart Entrepreneur Model (SEM). The foundation of the initial research and the need for a representative model requires a developed model that uses Exploratory Factor Analysis (EFA). Testing the validity of this construct is a process that is in line with the development of the measured concept, explores empirical data, and detects the characteristics of the relationship between variables[14, 15]. Thus, this study analyzes the Smart Entrepreneur Model (SEM) construct validity to obtain a representative model for developing student entrepreneurial skills in Indonesia, especially in Engineering Education.

\section{MAterial AND Method}

\section{A. Related Works}

Developing countries have significant weaknesses in the entrepreneurial culture and human resources [16, 17]. University partnerships with national and international organizations are also essential for disseminating knowledge and entrepreneurial mindset. The University network is considered one of the most critical factors as a vehicle for knowledge transfer between universities, young entrepreneurs, and other economic actors. Two essential dimensions that influence successful entrepreneurship are individual human capital and the business environment in which individuals operate $[18,19]$.

The SEM entrepreneurship training model becomes a conceptual framework that serves as a guide for trainers or instructors in conducting training that has been structured systematically. Testing this training model will be carried out in the second year of the study. In the first year of this study, the entrepreneurship training model was conducted to develop the conceptual framework of the SEM entrepreneurship training model and the tools used to implement it.

SEM Entrepreneurship Training Model has specifications to be characterized as a Model. It aims to be able to distinguish between learning models, strategies, and learning methods. The Learning Model has several attributes that are not possessed by specific strategies and learning methods $[20$, 21]. Attributes of a Model are a coherent theoretical basis or a point of view about what should be learned and how they learn. Learning models recommend the various teaching 
behaviors and class structures needed to realize different types of learning.

To realize the SEM model, standard' objectives are needed. A critical part of the model is the application of an appropriate framework for treatment delivery. The proper framework will contribute to the entrepreneurship index's achievement as an indicator of the treatment model. The entrepreneurship index, one of the focuses in this SEM model, is entrepreneurship attitude, related to how an individual becomes an entrepreneur or works in an organization [22]. Internal locus of control, the individual's belief, is the individual who controls his way of life[16, 23]. Motivation is a catalyst that encourages individuals to behave or have activities under their goals [24]. Self-confidence means achievement expectation based on evaluation of performance. The need for achievement is related to the desire to master complex challenges and compete with other people $[25,26]$. The other entrepreneurship indexes take simple risks, entrepreneurial moral values of entrepreneurship, entrepreneurial thought, and entrepreneurial behavior.

\section{B. Participants}

To validate the SEM model, a component of the model was tested. The test involved nine experts who had track records in entrepreneurship, vocational education, and engineering education. Retrieval of data using a model validation instrument that considered the depth of the model and its practicality was applied. As stated earlier, the focus of the discussion in this paper deals with the SEM model' construct testing involving 72 students as the sample. The sample participated in core training using SEM. Data retrieval of the sample was carried out using the entrepreneurship index questionnaire.

The questionnaire consists of several statements formulated in the form of questions or statements with five options in the form of attitude scales and frequency scales adapted to the purpose of the question or statement [27]. They are 1) Attitude Scale: Strongly Agree (SA), Agree (A), Somewhat Disagree (SD), Disagree (DA), and Strongly Disagree (SDA); 2) Frequency Scale: Always (A), Often (O), Sometimes (S), Rarely (R), and Never (N). The use of attitude scale and frequency scale addressed the need of each research variable. Following the nature of the questionnaire, the weight of the statement items/positive questions used a score of $5,4,3,2$, and 1 . The statement/negative question statements also used a score of 1, 2, 3, 4, and 5.

\section{Content Validity Analysis Methods}

To measure the content validity, the content validity ratio (CVR) approach was used to through which item's essential was investigated[28]. This measurement uses a five-point Likert scale with a formula $\mathrm{CVR}=(\mathrm{Ne}-\mathrm{N} / 2) /(\mathrm{N} / 2)$, which $\mathrm{N}$ is the number of specialists, and $\mathrm{Ne}$ is the number of specialists who indicated item's essential. According to The Lawshe Table, a CVR of more than 0.78 was meaningful and acceptable based on the number of panelists [28].

The nine experts conducted this measurement to validate seven aspects of the model. As seen in Table I below, all aspects of the model get a CVR score of more than 0.78 . This means that the SEM entrepreneurship training model meets the requirements of content validity.
TABLE I

VALUE OF CONTENT VALIDITY RATIO (CVR) OF SEM ENTREPRENEURSHIP TRAINING MODEL

\begin{tabular}{lc}
\hline Validation Aspect of Model & CVR \\
\hline Rational Model & .91 \\
Supporting Model Theory & .84 \\
Characteristics of Model & .90 \\
Model Syntax & .88 \\
Social System & .89 \\
Principles of Reaction & .87 \\
Supporting System & .86 \\
\hline
\end{tabular}

\section{Construct Validity Analysis Methods}

This research method used a research and development approach [29]. It was carried out in three phases. Phase I involves needs analysis and designing Smart Entrepreneur Model (SEM). Phase II includes Validation testing, Expert opinion test (formative evaluation), and Statistic test Exploratory Factor Analysis (EFA). Phase III consists of the Implementation of the Smart Entrepreneur Model (SEM), Field test (summative evaluation), and Dissemination.

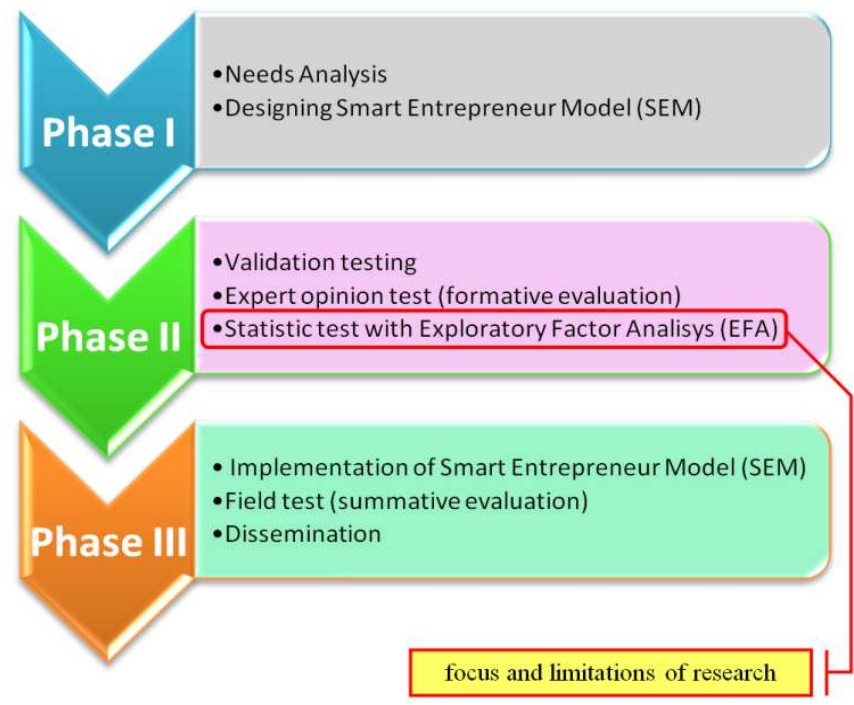

Fig. 1 Focus and Limitation of Research

This article will only focus on Phase II, Statistic test Exploratory Factor Analysis (EFA). It is concerned with describing and analyzing the smart Entrepreneur Model (SEM) construct validity using Exploratory Factor Analysis (EFA). The construct validity analysis was to test whether the phase had the validity of the construct or not. Confirmatory Factor Analysis using IBM SPSS Amos 20 software to examine whether the phases that had been developed could confirm the overall construct of the model. The questionnaire consisting of 40 questions that was distributed to 72 students was analyzed to obtain the data.

The stages of statistical tests with Exploratory Factor Analysis (EFA), as for the steps according to [16, 23, 30-32], are as follows:

1) Emperor Mayer Olkin (KMO) and Barlett's Test: The KMO test and Barlett's test were used to assess whether the variables to be analyzed had the eligibility to be used as a forming factor or not. In this test, the requirements that must be met in this test are the KMO MSA value greater than 0.05 and Bartlett's Test of Sphericity (Sig.) A value less than 0.05 . 
2) Anti-Image Matrices: This test aims to determine and determine which variables are suitable for use in factor analysis. The requirement that must be met in this test is an MSA value greater than 0.05 .

3) Communalities: This test aims to show the variable under study's value, whether it can explain the factor or not. A variable can explain the factor if the Extraction value is more significant than 0.05 .

4) Total Variance Explained: This test aims to show the value of each variable being analyzed. In this test, two parts of the analysis explain a variant, namely Initial Eigenvalues and Extraction Sums of Squared Loadings. The Initial Eigenvalues variant shows the formed factor, while the Extraction Sums of Squared Loadings section show the number of variations or the number of factors that can be formed.

5) Scree Plot: Scree Plot shows the number of factors that are formed. It is implemented by looking at the Component point value that has an Eigenvalue value greater than 1 .

6) Component Matrix: It shows the correlation value or the relationship between each variable and the factor that will be formed. The results of the data can be seen with a correlation value that is close to 1 .

7) Rotated Component Matrix: It aims to ascertain which factor is included in which factor group. It can be determined by looking at the value of the most considerable correlation between the variable and the formed factor (Component).

8) Component Transformation Matrix: This shows whether the factors formed are no longer correlated with one another.

\section{RESULTS AND DisCUSSION}

\section{A. Rationalized on the Development of SEM Entrepreneurship Training Model}

Universitas Negeri Padang (henceforth UNP) is one of the State Universities that organizes PMW. Implementing PMW through the discourse on integrated Entrepreneurial Campus becomes a responsibility of UNP to increase Indonesian nation welfare. Therefore, UNP runs the government programs concerning entrepreneurial activities by referring to the predetermined standard of activities. Unfortunately, the PMW program has not been satisfactory. This is reflected in the data presented by the Head of the PMW team of UNP from 2009 to 2014 . Of the 378 proposed business proposals, only $81(21.42 \%)$ proposals were funded. This figure indicates that the quality of the proposals submitted did not meet the determined criteria of assessment. Then, of the 81 business proposals funded, only $25(30.86 \%)$ ran well, while 56 (69.14\%) businesses did not work for various problems, mostly related to students' lack of business management. This problem confirms that even though the government has provided a massive budget to implement this program, its implementation is still beyond expectation. Lack of knowledge about the concept of entrepreneurship, attitude, and characters of Entrepreneurship, low management skills, inadequate mastery of information technology needs to be overcome through a Training Model.

\section{B. The Smart Entrepreneur Model (SEM) Entrepreneurship Training Model Phase}

The phase consists of operational steps of learning. The Smart Entrepreneur Model (SEM) steps were prepared according to the needs of the training.

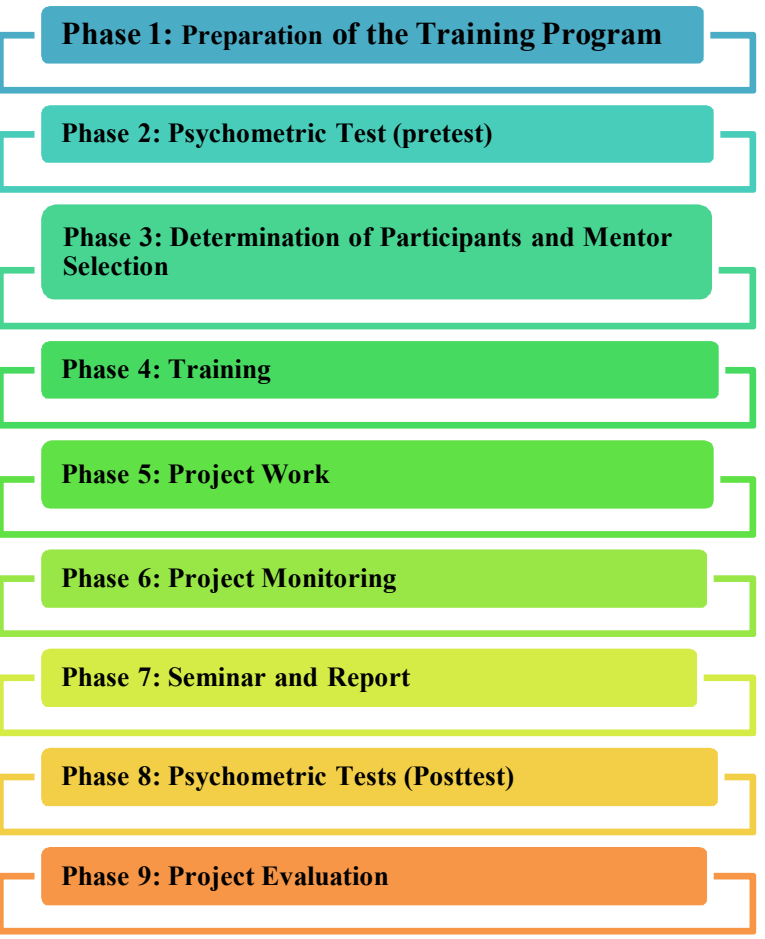

Fig. 2 The Smart Entrepreneur Model (SEM) Entrepreneurship Training Model Phase

The description of each phase of the Training Model can be briefly stated as follows:

1) Phase 1. Preparation of the Training Program: Preparation for the Smart Entrepreneur Model (SEM) training was carried out to provide opportunities for participants to prepare themselves for training.

2) Phase 2. Psychometric Test (pretest): In this phase, the participants did a psychometric test to assess the stage (index) of entrepreneurship that the trainees have. The test results become recommendations for the mentor's approach to direct the participants to their entrepreneurial careers. This was followed by identifying psychometric results to show the entrepreneurial abilities of the participants according to the development of their interests, talents, and personal potential.

3) Phase 3. Determination of Participants and Mentor Selection: In the third phase, based on the psychometric test results, the training participants were classified according to their abilities and determined by the mentors' characteristics. The participants carried out entrepreneurship tasks and the mentor considered the training participants' experiences.

4) Phase 4. Training: The training participants were given training and coaching about the entrepreneurial mindset and entrepreneurial processes. It was conducted in the learning class context by providing material according to the predetermined training curriculum. 
5) Phase 5. Project Work: At this phase, the participants directly practiced in the field with a mentor. They were guided to carry out all entrepreneurial process activities and business management through mentor's supervision.

6) Phase 6. Project Monitoring: Monitoring of project implementation was acted upon by the participants and the mentors. The activities were checked through diary writing and the progress of the project progress assessment.

7) Phase 7. Seminar and Report: This phase was carried out at the final stage after completing the training activities. The participants were asked to report business progress based on the assessment of the business progress carried out for one month.

8) Phase 8. Psychometric Tests (Posttest): At this stage, the participants' entrepreneurial index using the PIKEN test application was remeasured.

9) Phase 9. Project Evaluation: Evaluation was carried out by the instructor to assess the success of the training participants' efforts based on the reports and presentations made related to entrepreneurial activities of the participants and to conduct a pretest by measuring the entrepreneurial index of the retraining participants.

\section{Construct Validity Test Based on Statistical Analysis of Exploratory Factor Analysis (EFA)}

Validity analysis was to test whether the phase has validity analyzed using EFA to find out the extent to which the phases that have been developed can confirm the construct of the model. The following research reports the model validity analysis based on the Phase model:

1) Kaisar Mayer Olkin (KMO) and Bartlett's Test: The $\mathrm{KMO}$ test and Barlett's test were used to assess the eligibility of the variables to be used as determinant factors. The following are the analysis of the KMO test and Barlett's test of research variables.

TABLE II

RESULTS OF VARIABLE FEASIBILITY ANALYSIS

\begin{tabular}{llr}
\hline \multicolumn{3}{c}{ KMO and Bartlett's Test } \\
\hline Kaiser-Meyer-Olkin Measure of Sampling Adequacy. & .832 \\
Bartlett's Test of Sphericity & Approx. Chi-Square r & 848.998 \\
& Df & 36 \\
& Sig. & .000 \\
\hline
\end{tabular}

Based on the results in Table II, the Kaiser-Mayer Olkin Measure of Sampling Adequacy (KMO) score shows a score of $0.832>0.500$. Thus, it can be stated that all variables are suitable for further analysis. The result of the Bartlett of Sphericity shows a correlation between variables showing a significant score at $0.000<0.050$, meaning that factor analysis can be continued.

2) Anti-Image Matrices: Based on the result of the analysis depicted in Table III Anti-image Matrices, it can be seen that the price of Measures of Sampling Adequacy (MSA) is listed in the anti-image correlation column is all variables> 0.50 . It means that all variables can be further processed, and no variables should be discarded.
TABLE III

ANTI-IMAGE MATRICES

\begin{tabular}{|c|c|c|c|c|c|c|c|c|c|c|}
\hline \multicolumn{11}{|c|}{ Anti-image Matrices Phases } \\
\hline & & 1 & 2 & 3 & 4 & 5 & 6 & 7 & 8 & 9 \\
\hline \multirow{9}{*}{$\begin{array}{l}\text { Anti- } \\
\text { image } \\
\text { Covaria } \\
\text { nce }\end{array}$} & Phase 1 & .344 & -.138 & .021 & -.048 & .004 & .018 & -.021 & -.009 & -.008 \\
\hline & Phase2 & -.138 & .236 & -.030 & -.074 & .006 & -.017 & .058 & -.004 & .003 \\
\hline & Phase3 & .021 & -.030 & .343 & -.135 & .017 & -.006 & -.130 & -.015 & .001 \\
\hline & Phase 4 & -.048 & -.074 & -.135 & .200 & -.018 & .003 & .025 & .014 & .000 \\
\hline & Phase 5 & .004 & .006 & .017 & -.018 & .016 & .002 & -.008 & -.016 & -.003 \\
\hline & Phase6 & .018 & -.017 & -.006 & .003 & .002 & .045 & .010 & -.003 & -.043 \\
\hline & Phase 7 & -.021 & .058 & -.130 & .025 & -.008 & .010 & .596 & .001 & -.016 \\
\hline & Phase8 & -.009 & -.004 & -.015 & .014 & -.016 & -.003 & .001 & .017 & .003 \\
\hline & Phase9 & -.008 & .003 & .001 & .000 & -.003 & -.043 & -.016 & .003 & .048 \\
\hline \multirow{9}{*}{$\begin{array}{l}\text { Anti- } \\
\text { image } \\
\text { Correlati } \\
\text { on }\end{array}$} & Phase 1 & $.898^{\mathrm{a}}$ & -.483 & .062 & -.182 & .060 & .141 & -.047 & -.119 & -.063 \\
\hline & Phase2 & -.483 & $.888^{\mathrm{a}}$ & -.106 & -.342 & .092 & -.167 & .155 & -.065 & .032 \\
\hline & Phase3 & .062 & -.106 & $.863^{\mathrm{a}}$ & -.516 & .221 & -.045 & -.288 & -.192 & .009 \\
\hline & Phase4 & -.182 & -.342 & -.516 & $.863^{\mathrm{a}}$ & -.314 & .033 & .072 & .237 & .003 \\
\hline & Phase 5 & .060 & .092 & .221 & -.314 & $.781^{\mathrm{a}}$ & .071 & -.085 & -.970 & -.115 \\
\hline & Phase6 & .141 & -.167 & -.045 & .033 & .071 & $.792^{\mathrm{a}}$ & .058 & -.115 & -.935 \\
\hline & Phase 7 & -.047 & .155 & -.288 & .072 & -.085 & .058 & $.929^{\mathrm{a}}$ & .008 & -.098 \\
\hline & Phase8 & -.119 & -.065 & -.192 & .237 & -.970 & -.115 & .008 & $.788^{\mathrm{a}}$ & .114 \\
\hline & Phase9 & -.063 & .032 & .009 & .003 & -.115 & -.935 & -.098 & .114 & $.795^{\mathrm{a}}$ \\
\hline
\end{tabular}

3) Communalities: commonalities are the total variance explained by the extracted factor. In the confirmatory factor analysis, only the common variance is analyzed to be acceptable when the value of the common variance $<1$. The result of the analysis of commonalities using IBM SPSS Amos 20 is presented in the following Table.

TABLE IV

COMMUNALITIES VALUES

\begin{tabular}{lcc}
\hline & Communalities \\
\hline Phase1 & Initial & Extraction \\
Phase2 & 1.000 & .573 \\
Phase3 & 1.000 & .693 \\
Phase4 & 1.000 & .599 \\
Phase5 & 1.000 & .745 \\
Phase6 & 1.000 & .810 \\
Phase7 & 1.000 & .726 \\
Phase8 & 1.000 & .380 \\
Phase9 & 1.000 & .810 \\
\hline
\end{tabular}

Extraction Method: Principal Component Analysis.

The result of the analysis depicted in Table IV shows the extent to which the formed factor can explain the variance of each phase of SEM. For instance:

- The data in Phase1 is 0.573; this shows that around $57.3 \%$ of the variance of the Smart Entrepreneur Model syntax in Phasel can be explained by the formed factors,

- The data in Phase 2 is 0.693 ; this shows that around $69.3 \%$ of the variance of the Smart Entrepreneur Model syntax in Phase 2 can be explained by the formed factors,

- The data in Phase 3 is 0.599 ; this shows that around $59.9 \%$ of the variance of the Smart Entrepreneur Model 
syntax in Phase 3 can be explained by the formed factors, and so on.

4) Total Variance Explained: The following Table V indicates the Total Variance Explained analysis results to determine the number of factors formed from the factor analysis.

TABLE V

TOTAL VARIANCE EXPLAINED SCORE OF FACTOR ANALYSIS

\begin{tabular}{|c|c|c|c|c|c|c|}
\hline \multicolumn{7}{|c|}{ Total Variance Explained } \\
\hline \multirow{2}{*}{$\begin{array}{c}\text { Compon } \\
\text { ent }\end{array}$} & \multicolumn{3}{|c|}{ Initial Eigenvalues } & \multicolumn{3}{|c|}{$\begin{array}{c}\text { Extraction Sums of Squared } \\
\text { Loadings }\end{array}$} \\
\hline & $\begin{array}{c}\text { Tota } \\
1\end{array}$ & $\begin{array}{c}\% \text { of } \\
\text { variance }\end{array}$ & $\begin{array}{l}\text { Cumulativ } \\
\text { e } \%\end{array}$ & Total & $\begin{array}{c}\% \text { of } \\
\text { variance }\end{array}$ & $\begin{array}{c}\text { Cumulativ } \\
\text { e } \%\end{array}$ \\
\hline 1 & $\begin{array}{r}6.05 \\
3\end{array}$ & 67.258 & 67.258 & 6.053 & 67.258 & 67.258 \\
\hline 2 & .966 & 10.737 & 77.996 & & & \\
\hline 3 & .707 & 7.859 & 85.855 & & & \\
\hline 4 & .537 & 5.971 & 91.826 & & & \\
\hline 5 & .365 & 4.061 & 95.887 & & & \\
\hline 6 & .186 & 2.070 & 97.957 & & & \\
\hline 7 & .151 & 1.680 & 99.637 & & & \\
\hline 8 & .024 & .269 & 99.907 & & & \\
\hline 9 & .008 & .093 & 100.000 & & & \\
\hline
\end{tabular}

Extraction Method: Principal Component Analysis.

Based on Table 5, it can be explained that the factor that is formed is only 1 factor that has Eigenvalues $>1$. In Table V above, the factors formed with eigenvalues 6.053, explaining the model by $67.25 \%$ whole.

5) Scree Plot: Based on Figure 3, the Scree Plot can explain the nine components (phases) tested. There was only one component that had an Eigenvalue number of more than 1 .

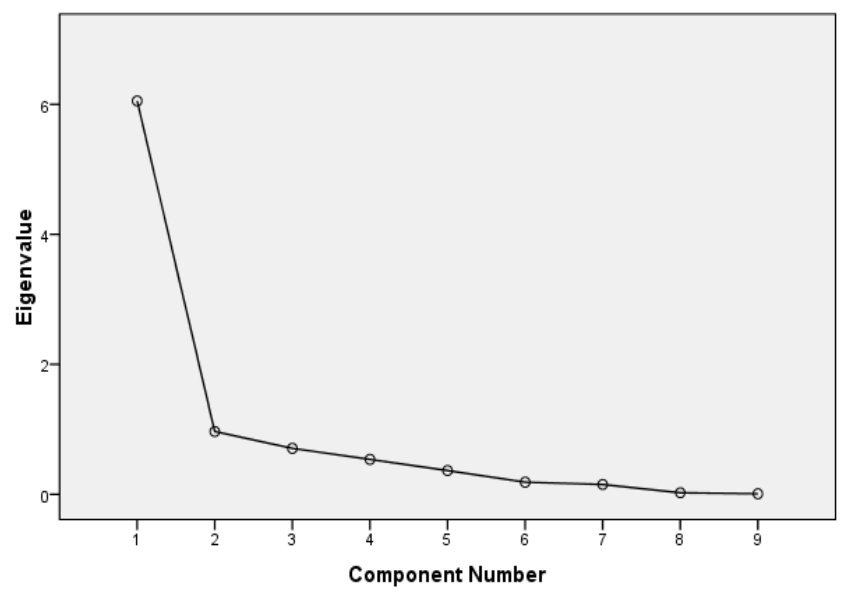

Fig. 3 Scree Plot 9 Phase of SEM

It was stated that the nine existing components had formed one factor. If it is related to the formation of phases in this learning model's trial, it can be concluded that the 9 phases tested have formed a complete unified model. Thus, the SEM entrepreneurship training model is valid based on factor analysis. One phase is formed from phases that have a unified form in the eigenvalue data.
6) Component Matrix: Based on the formation of factors in the Total Variance Explained, it is obvious that a learning model consisting of nine phases has been formed. Thus, there is no factor rotation because there is only 1 component of the formation. This can be seen in the following Table VI:

TABLE VI

TOTAL COMPONENT MATRIX

\begin{tabular}{cc}
\hline & Component Matrix \\
\hline & Component \\
\hline Phase1 & $\mathbf{1}$ \\
Phase2 & .757 \\
Phase3 & .833 \\
Phase4 & .774 \\
Phase5 & .863 \\
Phase6 & .900 \\
Phase7 & .852 \\
Phase8 & .616 \\
Phase9 & .900 \\
\hline
\end{tabular}

Extraction Method: Principal Component Analysis.

Table VI presents the figures indicating the loading factors or the correlation between indicators with only one component. As no indicator has a significant difference from the other indicators and there is no correlation $<0.5$, the indicator can be included into a factor or component depending on the degree of its correlation. Based on the result of this analysis, only one component formed from the phases; thus, factor rotation was not needed

7) Rotated Component Matrix: From the results of the Component Matrix described above, it is obvious that there are no components that can be rotated because only one factor is formed. The following statistical analysis result confirms that the rotation data does not have a component to rotate.

Rotated Component Matrix ${ }^{3}$

a. Only one component was extracted. The solution cannot be rotated.

Rotated Component Matrix is the result of the rotation of matrix components. This aims to show a clearer and more significant distribution of components than if no rotation was performed, with a limiting number of more than 0.5. Because of that, there was no component to be rotated because there was only one component was formed.

8) Component Transformation Matrix: The data of the component transformation matrix serves to show whether the factors formed are no longer correlated with each other. Because the data formed had no more than one component, the data could not be read diagonally. It means that the phases proposed in the trial are valid into one component of the formation. The rotation varimax method was used at the matrix transformation component to minimize the number of variables with high loading in one factor or component. This makes interpretation easier because the variable in the factor can be seen clearly. Only one component was formed in the matrix transformation component so that the nine phases were correlated with the component. This suggests that the nine phases proposed as the steps to apply the SEM training model 
are valid and cannot be separated from each other, as shown in Table VII

TABLE VII

COMPONENT TRANSFORMATION MATRIX

Component Score Coefficient Matrix

\begin{tabular}{lc}
\hline & Component \\
\hline Phase1 & 1 \\
\hline Phase2 & .125 \\
Phase3 & .138 \\
Phase4 & .128 \\
Phase5 & .143 \\
Phase6 & .149 \\
Phase7 & .141 \\
Phase8 & .102 \\
Phase9 & .149 \\
\hline
\end{tabular}

Extraction Method: Principal Component Analysis.

Rotation Method: Varimax with Kaiser Normalization.

Based on the analysis previously described, the results of this factor analysis are valid because of the 9 phases tested. There is only one component that has an Eigenvalue number of more than 1. Thus, it can be stated that the 9 phases have formed one factor. In terms of the formation of phases in this learning model's trial, it can be concluded that the 9 phases tested have formed a complete unified model. The SEM entrepreneurship training model is valid based on the Exploratory Factor Analysis. One phase is formed from phases that have a unified form in the eigenvalue data. These results used EFA- exploring empirical data to detect characteristics and relationships between variables without determining the model on the data $[10,14]$. In short, the SEM model helps shape students' entrepreneurial character and competence in entrepreneurship. In line with this, this entrepreneurial training and learning model and learning activities produce products that have commercial potential in higher education [33-37].

Furthermore, this training model, similar to a Learning Model, aims to improve students' ability to carry out entrepreneurial activities [17, 38, 39]. The training and learning model is also expected to positively impact students' entrepreneurial interest, entrepreneurial character, and entrepreneurial readiness [40-42]. The development of this SEM training model is deemed necessary to facilitate the training process for students of Universitas Negeri Padang. They are members of the Entrepreneurial Student Program (ESP) established by the Directorate General of Engineering Education to address the unsuccessful ESP activities at the UNP student level.

\section{CONCLUSION}

This research reveals that the development of the SEM training model has the phases that have been attested valid. Training can be run in nine phases. Smart Entrepreneur Model is worth using as a guideline by a university that sets up a program to produce graduates who can develop themselves to be independent entrepreneurs in the advancement of technology and globalization according to their psychometric index. The model can be adjusted to the mentor selection, the needs of the training participants- which is a flexible feature of this model. In short, through Exploratory Factor analysis, it can be argued that the entrepreneurial training model is suitable for university students in Indonesia to support the PMW program by the Indonesian government.

\section{ACKNOWLEDGMENT}

The authors are grateful to the research team who helped carry out this research to complete this paper on time. Also, we are obliged to the Faculty of Tourism and Hospitality, Universitas Negeri Padang, to support this research.

\section{REFERENCES}

[1] I. Darmawan, B. E. Soetjipto, E. T. Djatmika, and H. Wahyono, "The development of the entrepreneurship learning design based on caring economics to enhance spirit of entrepreneurship and entrepreneurial intentions," (in English), Humanities Soc. Sci. Lett., Article vol. 9, no. 1, pp. 1-13, 2021, doi: 10.18488/JOURNAL.73.2021.91.1.13.

[2] J. Peranginangin and U. A. Bakar, "Antecedents of developing entrepreneurial orientation among college students in Indonesia," (in English), International Journal of Scientific and Technology Research, Article vol. 9, no. 2, pp. 3230-3237, 2020. [Online]. Available: https://www.scopus.com/inward/record.uri?eid=2-s2.0-

85079644191\&partnerID $=40 \&$ md5 $=267 \mathrm{ce} 28863554 \mathrm{c} 1$ eeeb34a547d7 $8 \mathrm{c} 27 \mathrm{f}$.

[3] R. P. Pradhan, M. B. Arvin, M. Nair, and S. E. Bennett, "The dynamics among entrepreneurship, innovation, and economic growth in the Eurozone countries," Journal of Policy Modeling, Article vol. 42, no. 5, pp. 1106-1122, 2020, doi: 10.1016/j.jpolmod.2020.01.004.

[4] L. Klapper and I. Love, "The impact of the financial crisis on new firm registration," Economics Letters, vol. 113, no. 1, pp. 1-4, 2011.

[5] F. Crecente, M. Sarabia, and M. T. del Val, "Climate change policy and entrepreneurial opportunities," Technological Forecasting and Social Change, vol. 163, p. 120446, 2021.

[6] R. Ibrahim, A. Boerhannoeddin, and K. K. Bakare, "The effect of soft skills and training methodology on employee performance," European Journal of Training and Development, 2017.

[7] G. A. Cadenas, E. A. Cantú, T. Spence, and A. Ruth, "Integrating critical consciousness and technology in entrepreneurship career development with diverse community college students," Journal of Career Development, vol. 47, no. 2, pp. 162-176, 2020.

[8] E. Hehman, J. Calanchini, J. K. Flake, and J. B. Leitner, "Establishing construct validity evidence for regional measures of explicit and implicit racial bias," Journal of Experimental Psychology: General, vol. 148, no. 6, p. 1022, 2019.

[9] M. M. Córcoles-Muñoz, G. Parra-Requena, M. J. Ruiz-Ortega, P. M. García-Villaverde, and F. J. Ramírez-Fernández, "Psychological and Biographical Determinants of Entrepreneurial Intention: Does the Learning Environment Act as a Mediator?," Administrative Sciences, vol. 9 , no. 2, p. 33, 2019.

[10] K. Esfandiar, M. Sharifi-Tehrani, S. Pratt, and L. Altinay, "Understanding entrepreneurial intentions: A developed integrated structural model approach," Journal of Business Research, vol. 94, pp. 172-182, 2019.

[11] S. Hutasuhut, B. Irwansyah, A. Rahmadsyah, and R. Aditia, "Impact of business models canvas learning on improving learning achievement and entrepreneurial intention," Cakrawala Pendidikan, vol. 39 , no. 1 , pp. 168-182, 2020.

[12] T. Turner and P. Gianiodis, "Entrepreneurship unleashed: Understanding entrepreneurial education outside of the business school," Journal of Small Business Management, vol. 56, no. 1, pp. 131-149, 2018.

[13] J. Halberstadt, J.-M. Timm, S. Kraus, and K. Gundolf, "Skills and knowledge management in higher education: how service learning can contribute to social entrepreneurial competence development," Journal of Knowledge Management, 2019.

[14] H. Sofyan, E. Anggereini, and J. Saadiah, "Development of E-Modules Based on Local Wisdom in Central Learning Model at Kindergartens in Jambi City," European J Educ. Res., vol. 8, no. 4, pp. 1137-1143, 2019. 
[15] A. Yulastri, H. Hidayat, Ganefri, S. Yondri, and I. Ifdil, "Contribution of production-based learning, student engagement, and locus of control towards entrepreneurship learning outcomes in engineering education," International Journal on Advanced Science, Engineering and Information Technology, Article vol. 10, no. 2, pp. 585-592, 2020, Art no. 9365, doi: 10.18517/ijaseit.10.2.9365.

[16] H. Hidayat, Z. Ardi, S. Herawati, and Z. Amrina, "The contribution of internal locus of control and self-concept to career maturity in vocational higher education," KnE Social Sciences, pp. 234-248, 2019.

[17] H. Hidayat, S. Herawati, E. Syahmaidi, A. Hidayati, and Z. Ardi, "Designing of technopreneurship scientific learning framework in vocational-based higher education in Indonesia," International Journal of Engineering and Technology (UAE), Article vol. 7, no. 4, pp. 123-127, 2018, doi: 10.14419/ijet.v7i4.9.20632.

[18] A. A. Lux, F. R. Macau, and K. A. Brown, "Putting the entrepreneur back into entrepreneurial ecosystems," International Journal of Entrepreneurial Behaviour and Research, Article vol. 26, no. 5, pp. 1011-1041, 2020, doi: 10.1108/IJEBR-01-2020-0031.

[19] W. Ragmoun and A. M. Alwehabie, "Sustainable human resource management (SHRM) and corporate social responsibility (CSR): An Integrated Mediated Moderation Model of dynamic capabilities (DC) on family business industry," Management Science Letters, Article vol. 10, no. 10, pp. 2259-2268, 2020, doi: 10.5267/j.msl.2020.3.009.

[20] X. Huang et al., "Interactive Visual Study of Multiple Attributes Learning Model of X-Ray Scattering Images," IEEE Transactions on Visualization and Computer Graphics, Article vol. 27, no. 2, pp. 13121321, 2021, Art no. 9240062, doi: 10.1109/TVCG.2020.3030384.

[21] D. Wang, M. Zhang, Y. Xu, W. Lu, J. Yang, and T. Zhang, "Metricbased meta-learning model for few-shot fault diagnosis under multiple limited data conditions," Mechanical Systems and Signal Processing, Article vol. 155, 2021, Art no. 107510, doi: 10.1016/j.ymssp.2020.107510.

[22] W. Nowiński, M. Y. Haddoud, K. Wach, and R. Schaefer, "Perceived public support and entrepreneurship attitudes: A little reciprocity can go a long way!" Journal of Vocational Behavior, Article vol. 121, 2020, Art no. 103474, doi: 10.1016/j.jvb.2020.103474.

[23] H. Hidayat, B. Y. Tamin, S. Herawati, Z. Ardi, and A. P. Muji, "The Contribution of Internal Locus of Control and Self-Concept to Career Maturity in Engineering Education," International Journal on Advanced Science, Engineering and Information Technology, Article vol. 10, no. 6, pp. 2282-2289, 2020, doi: 10.18517/ijaseit.10.6.11698.

[24] Z. Ardi, Neviyarni, and Daharnis, "Konselo app: The future of distance counseling and therapy applications based on android technology," (in English), International Journal of Innovation, Creativity and Change, Article vol. 5, no. 6, pp. 231-244, 2019.

[25] Z. Ardi, I. Sukmawati, I. Ifdil, A. Afdal, I. Rangka, and K. Suranata, "Exploring the acceptability of internet-based mental health mobile app services using network psychometrics analysis," in Journal of Physics: Conference Series, 2018, vol. 1114, no. 1: IOP Publishing, p. 012106.

[26] Z. Ardi, R. D. Febriani, I. Ifdil, and A. Afdal, "Android "karirKu" Software Development for Exploration of Career Trends based on Personality Types," in Journal of Physics: Conference Series, 2019, vol. 1339, 1 ed., doi: 10.1088/1742-6596/1339/1/012123.

[27] P. Mair, Modern psychometrics with R. Springer, 2018.

[28] F. Fathollahi-Dehkordi, Z. Farajzadegan, S. Hematti, and N. Motamedi, "Iranian Version of the Quality of Life in Adult Cancer Survivors (QLACS) Questionnaire: Examining Face and Content Validity, Exploratory Factor Analysis and Reliability," Shiraz E-Medical Journal, vol. 22, no. 2, 2021.
[29] M. W. Watkins, "Exploratory factor analysis: A guide to best practice," Journal of Black Psychology, vol. 44, no. 3, pp. 219-246, 2018.

[30] R. Maskey, J. Fei, and H.-O. Nguyen, "Use of exploratory factor analysis in maritime research," The Asian journal of shipping and logistics, vol. 34, no. 2, pp. 91-111, 2018.

[31] E. d. A. Moretti, R. Anholon, I. S. Rampasso, D. Silva, L. A. SantaEulalia, and P. S. d. A. Ignácio, "Main difficulties during RFID implementation: An exploratory factor analysis approach," Technology Analysis \& Strategic Management, vol. 31, no. 8, pp. 943956, 2019.

[32] D. Goretzko, T. T. H. Pham, and M. Bühner, "Exploratory factor analysis: Current use, methodological developments and recommendations for good practice," Current Psychology, pp. 1-12, 2019

[33] Ganefri, H. Hidayat, A. Yulastri, and S. Yondri, "Design of production-based entrepreneurship technology training model to improve the skills of engineering students," International Journal of Innovative Technology and Exploring Engineering, Article vol. 8, no. 11, pp. 2042-2047, 2019, doi: 10.35940/ijitee. K1930.0981119

[34] A. Bauman and C. Lucy, "Enhancing entrepreneurial education: Developing competencies for success," The International Journal of Management Education, p. 100293, 2019.

[35] Ganefri, H. Hidayat, I. Kusumaningrum, and A. Mardin, "Needs analysis of entrepreneurships pedagogy of technology and vocational education with production base learning approach in higher education," International Journal on Advanced Science, Engineering and Information Technology, Article vol. 7, no. 5, pp. 1701-1707, 2017 , doi: 10.18517/ijaseit.7.5.1510.

[36] A. P. Muji et al., "The effectiveness of the implementation of lesson plans based on entrepreneurial values in the kindergarten," International Journal of Scientific and Technology Research, Article vol. 8, no. 12, pp. 121-128, 2019.

[37] E. Syahmaidi, H. Hidayat, S. Hartanto, and A. F. Rahmadani, "Designing E-Training Computer Assisted Instruction Used to Pedagogic Competency in Vocational Education," 2021 2019, vol. 1779: IOP Publishing, 1 ed., p. 012038.

[38] H. Hidayat, "How to Implement Technology Science for Entrepreneurship by Using Product-Based Learning Approach and Participatory Action Learning System in Higher Education?" Advanced Science Letters, vol. 23, no. 11, pp. 10918-10921, 2017.

[39] H. Hidayat and Yuliana, "The influence of entrepreneurship education and family background on students' entrepreneurial interest in nutritious traditional food startups in Indonesia," International Journal of Engineering and Technology (UAE), Article vol. 7, no. 4, pp. 118122, 2018, doi: 10.14419/ijet.v7i4.9.20631.

[40] H. Hidayat, Z. Ardi, Yuliana, and S. Herawati, "Exploration of the need analysis for technopreneurship scientific learning models in higher vocational education," International Journal of Economics and Business Research, vol. 18, no. 3, pp. 356-368, 2019.

[41] A. Yulastri, N. A. Buang, Ernawati, and Ganefri, "The relationship between entrepreneurship knowledge, career personality interest and entrepreneurial career interest," International Journal of Innovative Technology and Exploring Engineering, Article vol. 8, no. 7, pp. 405 410, 2019.

[42] A. Yulastri, H. Hidayat, Ganefri, R. Ayu, and Z. Ardi, "An empirical study on the effects of pedagogy learning tools entrepreneurship with product-based learning approach, learning readiness, and locus of control: A case from engineering education in Indonesia," International Journal of Scientific and Technology Research, Article vol. 8 , no. 9 , pp. 1717-1721, 2019. 